- Increasing emphasis is being placed in dentistry, as in other areas, on outcome-based

education and on the specification of learning outcomes.

- The medical three circle model described by Harden has been adapted for dentistry and

offers an effective and user-friendly format for specifying learning outcomes throughout

the continuum of dental education.

- The model:

Has the potential to specify outcomes in all specialties and in different areas of dentistry

including vocational and general professional training, and in the professions

complimentary to dentistry.

Facilitates curriculum and examination planning, reconciles tensions between vocational

and academic education and is readily accepted by students and teachers.

\title{
The specification of learning outcomes in dentistry
}

\author{
J. D. Clark, ${ }^{1}$ L. J. Robertson ${ }^{2}$ and R. M. Harden ${ }^{3}$
}

Increasing emphasis is being placed in dentistry, as in other areas, on outcome-based education and on the specification of learning outcomes. This paper describes the adaptation for dentistry of the medical three circle model as described by Harden to specify learning outcomes. The model offers an effective and user-friendly format based on the three dimensions of the work of a dentist. What the dentist is able to do ('doing the right thing'), how the dentist approaches their practice ('doing the thing right'), and the dentist as a professional ('the right person doing it'). The model also facilitates curriculum and examination planning, reconciles tensions between vocational and academic education and is readily understood and accepted by students and teachers.

Outcome based education (OBE) is neither a new concept or a passing phase in education, and is equally applicable throughout the educational continuum in dentistry from undergraduate to postgraduate training..$^{1,2,3}$ OBE focuses on the end product and defines what the learner is accountable for. It is not about telling teachers how to teach, or students how to learn. Learning outcomes determine what is taught and assessed, and can help to identify what is and is not essential. A clearer definition of the desired outcomes does not necessarily have to be restricting, as the methods of achieving the outcomes are still flexible. The specification of outcomes is not new to dentistry but to date much of the work in

\footnotetext{
${ }^{1 *}$ Consultant Orthodontist, Tayside University NHS Trust, Dundee Dental Hospital and School, Park Place, Dundee, ${ }^{2}$ Senior Education Development Officer, ${ }^{3}$ Director of the Centre for Medical Education, University of Dundee, and Director of the Scottish Council for Postgraduate Medical and Dental Education's Education Development Unit, Dundee

*Correspondence to: Mr J. D. Clark, Consultant Orthodontist, Tayside University NHS Trust, Dundee Dental Hospital and School, Park Place, Dundee DD1 4HN Email:john.clarke@tuht.scot.nhs.uk
}

\section{Refereed Paper}

Received 31.05.02; Accepted 24.10.02

doi:10.1038/sj.bdj.4811042

๑) British Dental Journal 2003; 196: 289-294 dentistry has been based on detailed specification of competencies. ${ }^{4}$ The development of competency statements has been described by Chambers and Garrow ${ }^{5}$ who suggests that their format should comprise of a three part structure that includes a verb, direct object, and qualifying conditions including special circumstances, limitations and explicit outcomes. McCann et $a l^{6}$ illustrate the complexity of this approach in their paper which outlines the lessons learned from the competency-based curriculum initiative at Baylor College of Dentistry, which has taken three or four years to develop and is an ongoing process. There are clear advantages to defining the product of training in dentistry. However, there are serious limitations to these historic approaches that emphasize learning objectives rather than learning outcomes. In this paper we present an alternative framework for specifying learning outcomes in dentistry. ${ }^{7}$

\section{CRITERIA FOR SPECIFYING LEARNING OUTCOMES}

Harden et $a l^{8}$ have suggested that the specification of learning outcomes should be expressed in such a way that they:

- Reflect the type of dentist envisaged at the end of undergraduate and postgraduate training.

- Are clear and unambiguous. It should be possible to look at the list of outcomes and know what attributes we expect to find in dentists.

- Are manageable in terms of the number of outcomes and yet provide a clear overview of the undergraduate curriculum or postgraduate training programme.

- Should be sufficiently few in number to: (i) avoid the learner and teacher feeling overwhelmed by the details.

(ii) make a practical contribution to curriculum planning and postgraduate training by serving as a framework for the organisation of learning resources, and as a basis for assessment.

- Provide sufficient detail to address defined areas of competence and allow clarity of focus to assist planning an undergraduate curriculum or postgraduate training and communicating the learning outcomes expected.

- Should be defined at an appropriate level of generality and be adaptable to all phases of the undergraduate curriculum and early postgraduate training.

- Should assist with the development of 
'enabling' outcomes. The list of outcomes should allow a 'design down' approach, so that there is a progression of learning.

- Should represent a holistic approach to dentistry, clearly expressing the relationship between different outcomes and how outcomes should relate to each other.

\section{THE THREE CIRCLE MODEL FOR SPECIFYING LEARNING OUTCOMES IN MEDICINE}

The criteria for specifying learning outcomes are met in the 'three circle' model for classifying learning outcomes, based on the three dimensions of the work of a doctor. ${ }^{8}$ The starting point is the definition of the three essential elements of the competent and reflective practitioner. These are:

- What the doctor is able to do ('doing the right thing' - that is technical intelligencies).

- How the doctor approaches their practice ('doing the thing right' - intellectual, emotional, analytical and creative intelligencies).

- The doctor as a professional ('the right person doing it' - that is personal intelligencies).

Twelve domains related to the three essential elements have been identified.
These are:

What the doctor is able to do

- clinical skills

- practical procedures

- patient investigation

- patient management

- health promotion and disease prevention

- communication

- data and information handling skills

How the doctor approaches their practice

- understanding of basic and clinical sciences and underlying principles

- appropriate attitudes, ethical understanding and legal responsibilities

- appropriate decision making, clinical reasoning and judgement

\section{The doctor as a professional}

- professional development

- personal development

\section{THE ADAPTATION OF THE THREE CIRCLE MODEL FOR DENTISTRY}

The three dimensions are equally applicable to the work of a dentist and it was decided to adapt the medical model for dentistry to reflect the nature of dental practice.

Dentistry is a highly technical profession with the majority of patient encounters involving some form of interventive treatment, either operative or therapeutic. The outcomes were therefore grouped to more naturally follow the pattern of a patient encounter in the dental setting. (Figure 1) Thus, the three key 'tasks' or 'What the dentist is able to do' were identified as:

- Clinical information gathering - taking a full and relevant patient history, undertaking a comprehensive patient examination, and arranging and interpreting appropriate investigations.

- Treatment planning - planning a suitable course of treatment in line with the patient's needs and wishes, recognising when referral is appropriate.

- Treatment procedures - carrying out the specific treatment interventions required to restore/maintain the patient's oral health.

These tasks represent the practical aspects of patient care but the dentist brings much more than practical skills to the patient encounter. 'How the dentist approaches their practice' or what they bring to the treatment of each patient, therefore, was judged to include:

- Application of basic clinical sciences using knowledge of the basic medical and clinical sciences to ensure appropriate diagnosis and treatment.

- Clinical reasoning and judgement -

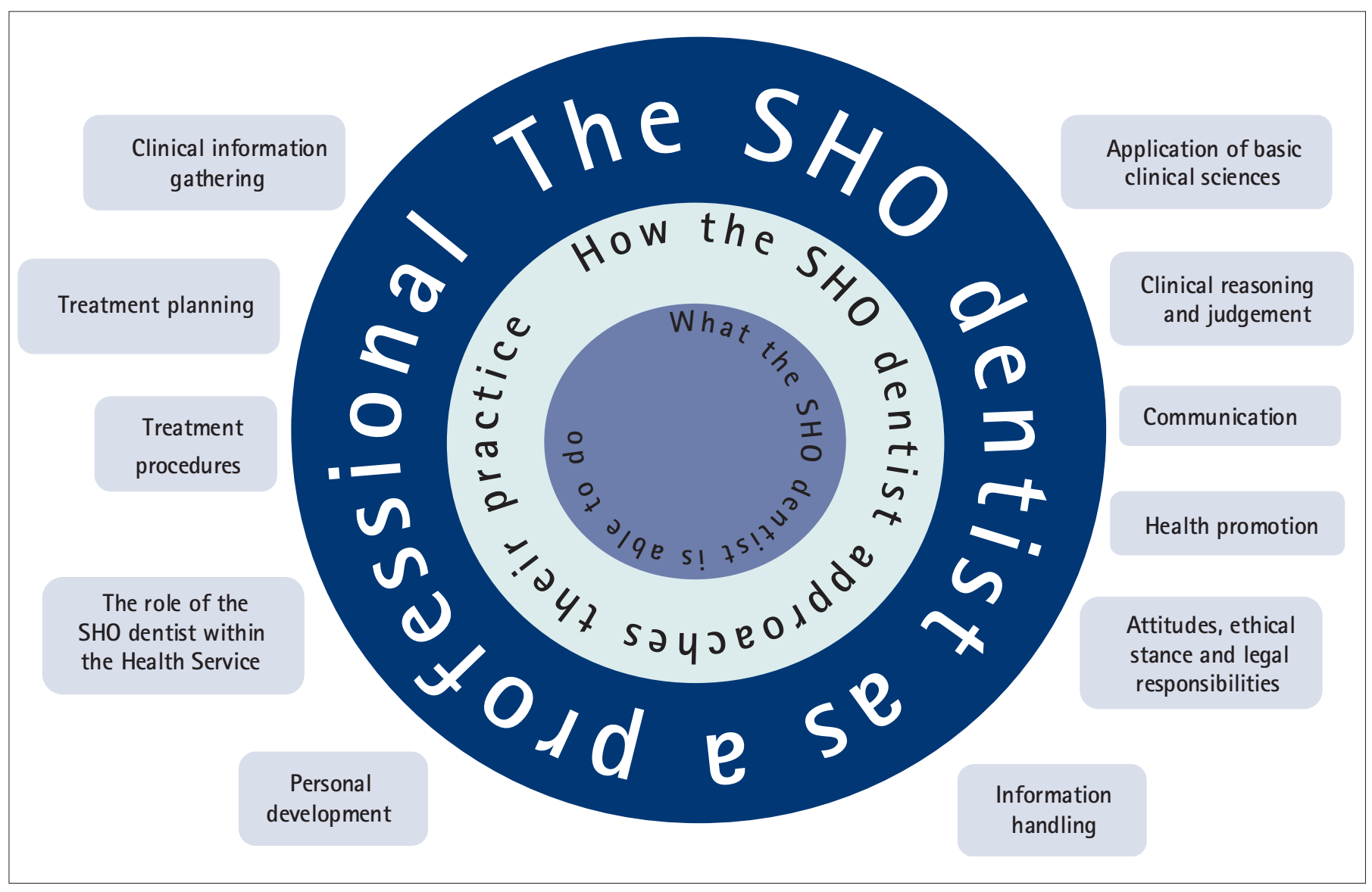

Figure 1 
using knowledge, evidence and professional judgement to arrive at solutions appropriate to the patient's needs and wishes.

- Communication - demonstrating appropriate communication skills with patients, relatives and other healthcare professionals.

- Health promotion - recognising the importance of disease prevention and health promotion and conveying this as appropriate to individual patients and the wider community.

- Attitudes, ethical stance and legal responsibilities - recognising ethical, professional and legal responsibilities and displaying appropriate attitudes and behaviour.

- Information handling - demonstrating accurate record keeping and knowing where and how to source and analyse information relevant to effective clinical practice.

The final dimension to the outcomes model is 'The dentist as a professional'. This encompasses:

- Role of the dentist within the health service - understanding the different dimensions of the dental profession and accepting the responsibilities that being part of that profession implies.

- Personal development - accepting responsibility for personal, career and continuing professional development.

These domains can be further sub-divided into more detailed learning outcomes. This is illustrated in Table 2 which shows the learning outcomes agreed as a result of a consultation exercise carried out in early 2000 by SHO educational supervisors at the three Scottish dental teaching hospitals. The degree of emphasis placed on each outcome and the level of detail to which it is taken will vary between different postgraduate training programmes and specialties, as will the learning and teaching methods which depend on the available resources. Inevitably there is overlap between some of the domains, with some outcomes being common to more than one domain. This serves to illustrate the inextricable links and interdependence between the different elements comprising a competent and reflective dentist.

The three circle model for dentistry has recently been adopted by the University Teachers of Orthodontics and the Standing Advisory Committee in Orthodontics to specify the learning outcomes for undergraduate, specialist (Figure 3) and consultant training in orthodontics - the importance of the continuum of learning is an important concept that is readily conveyed by this format.

\section{ADVANTAGES OF THE THREE CIRCLE MODEL FOR DENTISTRY}

The specification of learning outcomes using this model provides both teachers and students with a 'chart' which brings a focus and direction to teaching, learning and assessment. The advantages are summarised using the acronym CARE.

\section{Curriculum planning}

The model emphasises 11 key outcomes and makes possible a design down approach to more detailed specifications. This facilitates curriculum planning in undergraduate and postgraduate education, as agreement is more likely at the level of the 11 outcomes, even if there is disagreement at the lower levels of outcome. Thus the model serves as a firm foundation for further work on the curriculum. In the past, educational practice has concentrated on a more detailed lower level specification of learning objectives, which makes agreement more difficult.

While the specification of outcomes with the emphasis on product rather than process, should influence decisions taken about teaching and learning, it does not dictate specific educational approaches. Thus the five Scottish medical schools, all with different approaches to teaching and learning medicine and no history of agreement on educational issues were able to agree a common set of learning outcomes for the Scottish doctor. ${ }^{9}$ Using a similar approach, the Institute of International Medical Education was able to achieve an international agreement on the global requirements for medical education. ${ }^{10}$

The broad perspective offered by the model also allows areas of the curriculum which have been relatively neglected to be easily identified, thus ensuring that all aspects of the curriculum are addressed within the educational programme.

A further advantage of the model is that it is applicable to all phases of education, emphasising the continuum of dental education and the transition from one phase to the next. The framework can be applied to the range of postgraduate education including vocational training, general professional training and specialist training.

\section{Acceptance by students and teachers}

The three circle model provides a clear statement of significant exit outcomes and provides a macro perspective. It is readily understood by students and teachers and has sufficient detail to convey its meaning clearly but not too much to overwhelm the user. For both teachers and students, the three circle model provides an intuitive, user-friendly and transparent approach to communicating the learning outcomes of an education or training programme. The learning outcomes are performance-based and relate to the work of the dentist at the appropriate level of their training. This relevance and validity makes them more likely to be accepted by practising clinical teachers, enabling them to plan the content of their teaching and design their materials more effectively. Appropriate teaching and learning strategies can be selected by using the three circle model as a template for their teaching.

\section{Relationships between outcomes}

The model reconciles tensions between vocational and academic education, which are potentially destructive when planning an educational programme. Competencies necessary for effective dental practice are recognised in outcomes 1 to 3 (Table 2). The dentist, however, may have the skills to carry out the tasks of a dentist, but not the capabilities necessary for professional practice reflected in outcomes 4 to 10. Outcome 4 adds an important academic dimension. The sciences are seen not just as something to be learned and then forgotten, but as an important underpinning for dental practice and as part of the hallmark of a good dentist. The inter-relationship of outcomes, the evidence base and reflective nature of dental practice is emphasised, as is the coherent nature of the programme that students are required to study and understand. The personal development of the dentist as a professional and the dentist as an inquirer into his or her own competence is not overlooked. The holistic and integrated approach to dental education, and the interaction between the different outcomes is reinforced by the fact that it could be represented on a single A4 sheet (Table 2).

\section{Examination planning}

The three circles outcome model is a useful tool for planning assessments, allowing teachers to set a blueprint for examinations, ensuring that an appropriate mix of assessment tools are adopted to assess the range of learning outcomes. This is important both for summative and formative assessment. In formative assessment or appraisal it can encourage undergraduates and postgraduates to relate learning to competence by using a reflection record based on the 11 outcomes. Reflection on practice and learning experiences is the key to effective learning and professional development, and the reflection record provides a framework around which thoughts can be structured. 


\section{EDUCATION}

Table 1 The SHO dentist outcomes grid

\begin{tabular}{|c|c|c|c|c|c|}
\hline \multicolumn{3}{|c|}{ A } & \multicolumn{3}{|c|}{ B } \\
\hline \multicolumn{3}{|c|}{ Tasks (competences) } & \multicolumn{3}{|c|}{ What you bring to the tasks } \\
\hline $\begin{array}{l}1 \\
\text { Clinical information gathering }\end{array}$ & $\stackrel{2}{2}$ Treatment planning & $\begin{array}{c}3 \\
\text { Treatment procedures }\end{array}$ & $\begin{array}{c}4 \\
\text { Application of basic clinical } \\
\text { sciences }\end{array}$ & $\begin{array}{l}5 \\
\text { Clinical reasoning and } \\
\text { judgement }\end{array}$ & $\begin{array}{c}6 \\
\text { Communication }\end{array}$ \\
\hline $\begin{array}{l}\text { 1. Obtain and record an } \\
\text { accurate and } \\
\text { comprehensive dental/ } \\
\text { medical/ social history } \\
\text { including information on } \\
\text { diet and smoking where } \\
\text { appropriate. } \\
\text { 2. Perform intra- and extra- } \\
\text { oral examinations } \\
\text { comprising: } \\
\text { - TMJ and muscles of } \\
\text { mastication } \\
\text { - Periodontal } \\
\text { - Teeth } \\
\text { - Soft tissues and } \\
\text { lymph nodes } \\
\text { - Oral cancer } \\
\text { screening } \\
\text { - Skeletal pattern and } \\
\text { occlusal relationships } \\
\text { and function } \\
\text { 3. Arrange and interpret the } \\
\text { results of appropriate, } \\
\text { clinical, radiological and } \\
\text { laboratory investigations. }\end{array}$ & $\begin{array}{l}\text { 1. Develop a differential or } \\
\text { definitive diagnosis and } \\
\text { treatment plan. } \\
\text { 2. Plan appropriate } \\
\text { management of acute } \\
\text { dental conditions. } \\
\text { 3. Refer patients when } \\
\text { appropriate. } \\
\text { 4. Develop appropriate } \\
\text { sequence of treatment. } \\
\text { 5. Explain the treatment } \\
\text { plan and obtain informed } \\
\text { consent. } \\
\text { 6. Follow-up, monitor and } \\
\text { maintain care. }\end{array}$ & $\begin{array}{l}\text { 1. Anaesthesia/sedation. } \\
\text { 2. Restorative dentistry } \\
\text { comprising: } \\
\text { - Conservative } \\
\text { (including endodontics) } \\
\text { - Periodontology } \\
\text { - Prosthodontics } \\
\text { 3. Paediatric dentistry. } \\
\text { 4. Orthodontics. } \\
\text { 5. Oral surgery. } \\
\text { 6. Oral medicine. } \\
\text { 7. Laboratory disciplines } \\
\text { (oral pathology and } \\
\text { oral microbiology). } \\
\text { 8. Prevention. } \\
\text { 9. Management of } \\
\text { medical emergencies. }\end{array}$ & $\begin{array}{l}\text { 1. Recognition of normal and } \\
\text { abnormal structure, } \\
\text { function and behaviour } \\
\text { appropriate to the patient's } \\
\text { age, general health and } \\
\text { circumstances. } \\
\text { 2. Application of knowledge } \\
\text { of the pathophysiology of } \\
\text { common dental/ oral } \\
\text { health problems. } \\
\text { 3. Recognition of the potential } \\
\text { impact of medical history } \\
\text { on dental treatment. } \\
\text { 4. Application of } \\
\text { pharmacological theory } \\
\text { underpinning therapeutic } \\
\text { management. } \\
\text { 5. Application of the principles } \\
\text { of dental materials science } \\
\text { underpinning the safe and } \\
\text { effective selection of dental } \\
\text { materials. } \\
\text { 6. Application of behavioural } \\
\text { management techniques, } \\
\text { recognising the social, cultura } \\
\text { and psychological aspects of } \\
\text { patient care. } \\
\text { 7. Application of the principles } \\
\text { infection control to ensure sa } \\
\text { of patients and dental staff. }\end{array}$ & $\begin{array}{l}\text { 1. Assimilate and critically } \\
\text { analyse the clinical } \\
\text { history, examination and } \\
\text { investigation findings to } \\
\text { formulate a diagnosis and } \\
\text { identify potential solutions. } \\
\text { 2. Make decisions based on } \\
\text { evidence based practice. } \\
\text { 3. Formulate a plan of } \\
\text { action appropriate to the } \\
\text { needs and wishes of } \\
\text { the patient. } \\
\text { 4. Devise creative solutions } \\
\text { to problems and } \\
\text { restrictions encountered. } \\
\text { af }\end{array}$ & $\begin{array}{l}\text { 1. Demonstrate active } \\
\text { listening skills. } \\
\text { 2. Demonstrate appropriate } \\
\text { communication skills with } \\
\text { s. a range of patients. } \\
\text { 3. Demonstrate appropriate } \\
\text { communication skills } \\
\text { (verbal and written) with } \\
\text { other professional } \\
\text { colleagues. } \\
\text { 4. Demonstrate appropriate } \\
\text { communication skills with } \\
\text { dental staff in order to } \\
\text { ensure efficient and } \\
\text { effective teamwork. } \\
\text { 5. Demonstrate appropriate } \\
\text { case presentation skills } \\
\text { give appropriate advice } \\
\text { and information to } \\
\text { promote learning in others. }\end{array}$ \\
\hline
\end{tabular}

\section{Table 2 Outcome grid for the specialist in orthodontics}

\begin{tabular}{|c|c|c|c|c|c|}
\hline \multicolumn{3}{|c|}{ A } & \multicolumn{3}{|c|}{ B } \\
\hline \multicolumn{3}{|c|}{ What the specialist is able to do } & \multicolumn{3}{|c|}{ How the specialist approaches clinical practice } \\
\hline $\begin{array}{l}1 \\
\text { Clinical Information gathering }\end{array}$ & $\begin{array}{c}2 \\
\text { Treatment Planning }\end{array}$ & $\begin{array}{c}3 \\
\text { Treatment procedures }\end{array}$ & $\begin{array}{c}4 \\
\text { Application of basic clinical } \\
\text { sciences }\end{array}$ & $\begin{array}{l}5 \\
\text { Clinical reasoning and } \\
\text { judgement }\end{array}$ & $\begin{array}{c}6 \\
\text { Communication }\end{array}$ \\
\hline $\begin{array}{l}\text { 1. Take a history. } \\
\text { 2. Undertake an intra and } \\
\text { extra- oral examination } \\
\text { of the head and neck. } \\
\text { 3. Examine the occlusion. } \\
\text { 4. Obtain and interpret } \\
\text { relevant, clinical and } \\
\text { laboratory } \\
\text { investigation. }\end{array}$ & $\begin{array}{l}\text { 1. General principles. } \\
\text { 2. Craniofacial anomalies. } \\
\text { 3. Cleft lip and palate. } \\
\text { 4. Integrated restorative } \\
\text { care. } \\
\text { 5. Integrating oral and } \\
\text { maxillofacial surgery. } \\
\text { 6. Malocclusion and } \\
\text { medical problems. }\end{array}$ & $\begin{array}{l}\text { 1. Guiding the developing } \\
\text { occlusion. } \\
\text { 2. Adult orthodontics. } \\
\text { 3. Craniomandibular } \\
\text { dysfunctions. } \\
\text { 4. Interface with oral and } \\
\text { maxillofacial surgery. } \\
\text { 5. Interface with } \\
\text { restorative dentistry } \\
\text { including implantology. } \\
\text { 6. Interface with } \\
\text { paediatric dentistry. } \\
\text { 7. Appliances } \\
\text { - removable } \\
\text { - functional } \\
\text { - extra-oral } \\
\text { - fixed } \\
\text { - retention }\end{array}$ & $\begin{array}{l}\text { 1. General principles. } \\
\text { 2. Cell and molecular } \\
\text { biology. } \\
\text { 3. Genetics. } \\
\text { 4. Craniofacial } \\
\text { embryology. } \\
\text { 5. Somatic and } \\
\text { craniofacial growth. } \\
\text { 6. Physiology of breathing, } \\
\text { swallowing, mastication } \\
\text { and speech. } \\
\text { 7. Psychology. } \\
\text { 8. Dental materials. }\end{array}$ & $\begin{array}{l}\text { 1. General principles. } \\
\text { 2. Growth and treatment } \\
\text { analysis. } \\
\text { 3. Long term effects of } \\
\text { orthodontic treatment. } \\
\text { 4. latrogenic effects of } \\
\text { orthodontic treatment. }\end{array}$ & $\begin{array}{l}\text { 1. Demonstrate active } \\
\text { listening skills. } \\
\text { 2. Demonstrate appropriate } \\
\text { communication skills with } \\
\text { a range of patients. } \\
\text { 3. Demonstrate appropriate } \\
\text { communication skills } \\
\text { (verbal and written) with } \\
\text { other professional } \\
\text { colleagues. } \\
\text { 4. Demonstrate appropriate } \\
\text { communication skills with } \\
\text { others in the dental team } \\
\text { in order to ensure efficient } \\
\text { and effective teamwork. } \\
\text { 5. Demonstrate appropriate } \\
\text { case presentation skills, } \\
\text { give appropriate advice } \\
\text { and information to } \\
\text { promote learning in others. }\end{array}$ \\
\hline
\end{tabular}




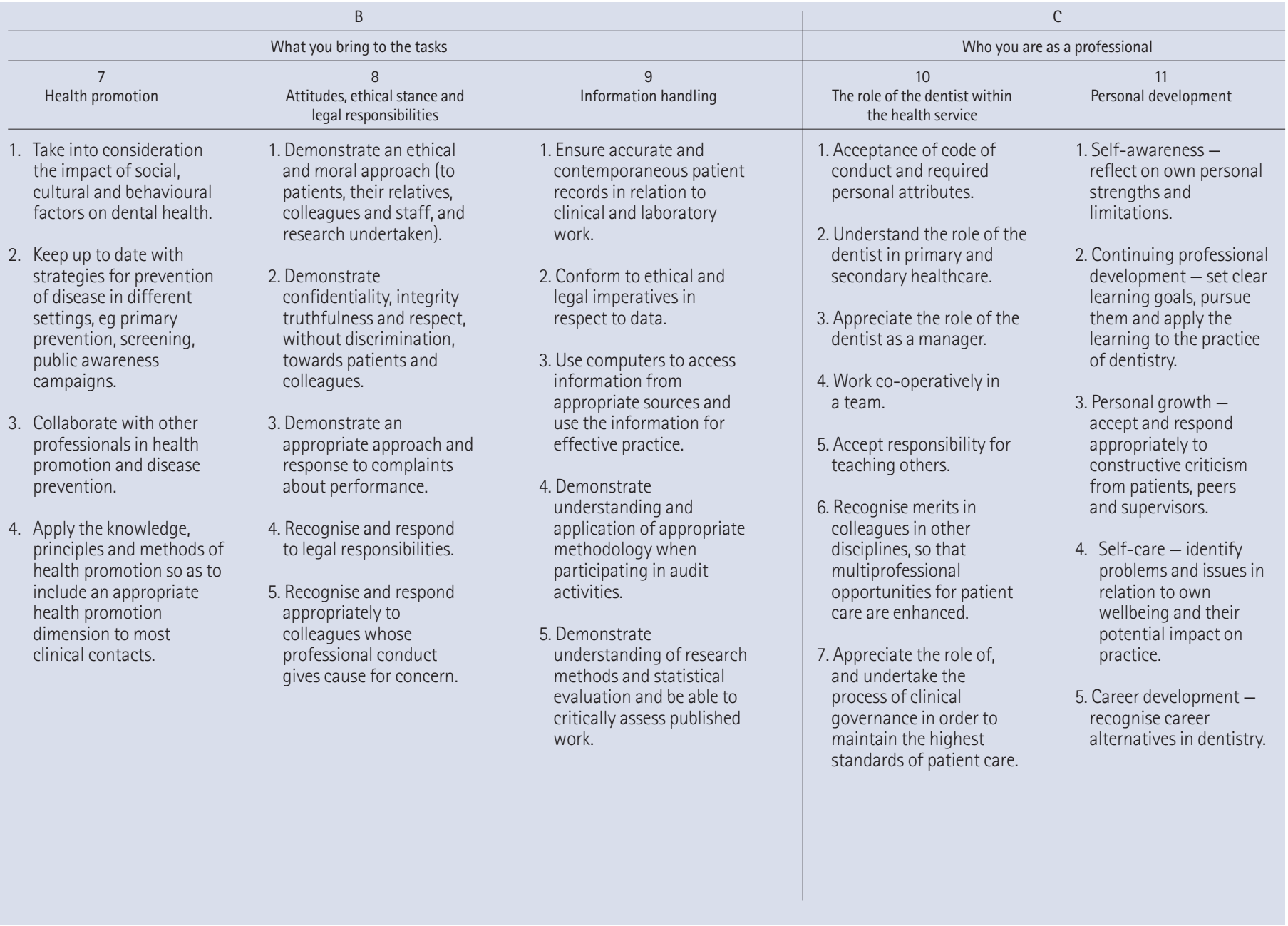

B

\begin{tabular}{|c|c|c|c|c|}
\hline \multicolumn{3}{|c|}{ How the specialist approaches clinical practice (continued) } & \multicolumn{2}{|c|}{ The specialist as a professional } \\
\hline $\begin{array}{c}7 \\
\text { Health Promotion }\end{array}$ & $\begin{array}{l}8 \\
\text { Attitudes, ethical stance and } \\
\text { legal responsibilities }\end{array}$ & $\stackrel{9}{\text { Information handling }}$ & $\begin{array}{l}10 \\
\text { The role of the dentist within } \\
\text { the health service }\end{array}$ & $\begin{array}{c}11 \\
\text { Personal development }\end{array}$ \\
\hline $\begin{array}{l}\text { 1. Take into consideration the } \\
\text { impact of social, cultural and } \\
\text { behavioural factors on } \\
\text { dental health. } \\
\text { 2. Keep up to date with strategies } \\
\text { for prevention of disease } \\
\text { in different settings, eg primary } \\
\text { prevention, screening, public } \\
\text { awareness campaigns. } \\
\text { 3. Collaborate with other } \\
\text { professionals in health } \\
\text { promotion and disease } \\
\text { prevention. } \\
\text { 4. Apply the knowledge, } \\
\text { principles and methods of } \\
\text { health promotion so as to } \\
\text { include an appropriate health } \\
\text { promotion dimension to } \\
\text { most clinical contacts }\end{array}$ & $\begin{array}{l}\text { 1. Demonstrate an understanding } \\
\text { of patient psychology in } \\
\text { relation to health. } \\
\text { 2. Demonstrate an ethical and } \\
\text { moral approach (to patients, } \\
\text { their relatives, colleagues and } \\
\text { staff, and research undertaken). } \\
\text { 3. Demonstrate confidentiality, } \\
\text { integrity, truthfulness and } \\
\text { respect, without discrimination } \\
\text { towards patients and } \\
\text { colleagues. } \\
\text { 4. Demonstrate an appropriate } \\
\text { approach and response to } \\
\text { complaints about performance. } \\
\text { 5. Recognise and respond to legal } \\
\text { responsibilities. } \\
\text { 6. Recognise and respond } \\
\text { appropriately to colleagues } \\
\text { whose professional conduct } \\
\text { gives cause for concern. }\end{array}$ & $\begin{array}{l}\text { 1. General principles. } \\
\text { 2. Computer based technology. }\end{array}$ & $\begin{array}{l}\text { 1. General. } \\
\text { 2. Health and safety. } \\
\text { 3. Legislation and ethics. } \\
\text { 4. Surgery management. } \\
\text { 5. Personnel management. } \\
\text { 6. Finance. } \\
\text { 7. Audit. } \\
\text { 8. Health service structures. }\end{array}$ & $\begin{array}{l}\text { 1. Self-awareness. } \\
\text { 2. Continuing professional } \\
\text { development. } \\
\text { 3. Personal growth. } \\
\text { 4. Self-care. } \\
\text { 5. Career development. } \\
\text { 6. Development of } \\
\text { additional experience } \\
\text { in areas of deficiency or } \\
\text { special interest. }\end{array}$ \\
\hline
\end{tabular}




\section{CONCLUSION}

Increasing emphasis is being placed in dentistry, as in other areas, on outcomebased education and on the specification of learning outcomes. The three circle model offers an effective and user-friendly format for specifying learning outcomes for teachers and students. The acceptability of this model is demonstrated by its adoption in medical education within the United Kingdom and the use of a similar approach by the Institute of International Medical Education to achieve international agreement on the global requirements for medical education. The successful and smooth adoption of this model for specifying learning outcomes in orthodontics throughout the continuum from undergraduate to specialist and consultant training suggests that it has the potential to specify outcomes in all specialties and in different areas of dentistry including vocational and general professional training. The foundation for this development must be the learning outcomes in the General Dental Council's (GDC) document, The First Five Years. When they are published they will be readily accommodated within the three circle model and reinforce the aim of the curriculum which is 'to produce a caring, knowledgeable, competent and skilful dentist who is able to accept professional responsibility for the effective and safe care of patients on graduation.' In addition, defining learning outcomes in the future for the professions complementary to dentistry will be made easier by the three circle model.

The authors acknowledge the support of the Scottish Council for Postgraduate Medical and Dental Education in funding this study. They are also grateful to the other members of the project steering group and to all those Educational Supervisors and SHOs who contributed their invaluable comments and feedback throughout the consultation exercise.

1. Spady W G. Organising for results: the basis of authentic restructuring and reform. Educ Leadership
1988. October: 9

2. Harden R M. Early postgraduate education and the strategy of the dolphins. Med Teach 1999; 21:365 369.

3. Harden R M. Developments in outcome-based education Med Teach 2002; 24: 117 - 120

4. Prescott LE, McKinlay P, Rennie J S. The development of an assessment system for dental vocational training and general professional training; a Scottish approach. Br Dent J 2001; 190: 41-44.

5. Chambers D W, Garrow J D. A manual for developing and formatting competency statements. J DentEduc 1994; 58: 361-366.

6. McCann A L, Babler W J, Cohen P A. Lessons learned from the competency based curriculum initiative at Baylor College of Dentistry. J Dent Educ 1998; 62: 197207.

7. Harden R M. Learning outcomes and instructional objectives - is there a difference? Med Teach 2002; 24: 151- 155.

8. Harden R M, Crosby J R, Davis M H, Friedman M. AMEE Guide No14: Outcome based education; Part 5from competency to meta-competency: a model for the specification of learning outcomes.

9. Simpson J G et al. The Scottish doctor - learning outcomes for the medical undergraduate in Scotland: a foundation for competent and reflective practitioners Med Teach 2002; 24: 136 - 143

10. Institute for International Medical Education. Global minimum essential requirements in medical education Med Teach 2002; 24: 130 - 135. 